\title{
Komparasi Kinerja Bank Syariáh Sebelum dan Sesudah Go Public
}

\author{
Asyari Hasan ${ }^{1}$, Sasa Parera ${ }^{2}$ \\ ${ }^{1}$ UIN Syarif Hidayatullah, Jakarta, Email : asyarihasan01@gmail.com \\ ${ }^{2}$ UIN Syarif Hidayatullah, Jakarta, Email : sasa912011@gmail.com
}

\begin{abstract}
Abstrak
Penelitian ini bertujuan menganalisa kinerja perbankan syariáh dengan maksud menemukan perbedaan dan perbandingan kinerja keuangan perbankan syariah setelah dan sebelum go public dengan menggunakan metode RGEC (Risk Profile, Good Corporate Governance, Earning, dan Capital). Penelitian ini menggunakan sampel laporan rasio kinerja keuangan dan laporan Good Corporate Governance (GCG) sebelum dan sesudah Go Public dengan menjadikan PT BRI Syariah Tbk yang telah dipublikasikan. Metode yang digunakan dalam penelitian ini adalah metode perbandingan uji statistik non parametrik dua sampel terkait (uji Wilcoxon). Hasil penelitian menunjukkan bahwa bank syariáh lebih baik setelah go public. Hal ini dapat dilihat dimana variabel Kewajiban Penyediaan Modal Minimum (KPMM) memiliki perbedaan yang cukup besar. Sedangkan variabel lainnya seperti Non Performing Fin ancing (NPF), Financing to Deposit Ratio (FDR), Return on Asset (ROA), Return on Equity (ROE), Net Operating Margin (NOM), dan Good Corporate Governance (GCG) memiliki perbedaan yang cukup kecil.
\end{abstract}

Kata kunci : Go public; RGEC; $C G C$; $C A R$

\begin{abstract}
This study aims to analyze the performance of Islamic banking with the intention of finding differences and comparisons of Islamic banking financial performance after and before going public using the RGEC method (Risk Profile, Good Corporate Governance, Earning, and Capital). This study uses a sample of financial performance ratio reports and Good Corporate Governance (GCG) reports before and after going public by making PT BRI Syariah Tbk which has been published. The method used in this study is the comparison method of the two-sample non-parametric statistical test (Wilcoxon test). The results showed that syariáh banks did better after going public. This can be seen where the Minimum Capital Adequacy Requirement (KPMM) variable has quite a big difference. Meanwhile, other variables such as Non-Performing Financing (NPF), Financing to Deposit Ratio (FDR), Return on Assets
\end{abstract}


(ROA), Return on Equity (ROE), Net Operating Margin (NOM), and Good Corporate Governance (GCG) have differences. which is quite small.

Keywords: Go-Public; RGEC; CAR; CGC

\section{Pendahuluan}

Meningkatnya dan berkembangnya minat masyarakat terhadap investasi menjadi salah satu alasan keputusan suatu perusahaan (termasuk perbankan Syariáh) secara umum untuk melakukan go public yaitu dengan cara mendaftarkan perusahaan dan melakukan penanaman serta penawaran saham perusahaan kepada masyarakat umum. Keadaan ini juga diudukug oleh Otoritas Jasa Keuangan (OJK) dengan gencar mengkampanyekan agar perusahaan mau menjadi go public. Hal ini dikarenakan bahwa pasar modal merupakan tempat yang sangat strategis bagi industri, termasuk bagi perbankan syariáh untuk memperoleh pendanaan jangka Panjang. Sebab suatu perusahaan dalam mengembangkan dan menjalankan usahanya membutuhkan modal untuk pendanaan. Perusahaan memiliki alternatif sumber pendanaan baik yang berasal dari dalam maupun luar perusahaan. Perusahaan dapat menggunakan laba ditahan sebagai sumber pendanaan internal perusahaan. Dana dari luar perusahaan dapat melalui sumber pendanaan yang berasal dari pinjaman, menerbitkan surat hutang atau obligasi, dan penerbitan saham baru. Proses awal pada saat melakukan go public yaitu melakukan penawaran saham perdana kepada masyarakat (IPO) (Rizqi dan Harto, 2013).

Investasi merupakan komitmen mengenai dana dan sumber daya lainnya yang bertujuan untuk menghasilkan keuntungan untuk masa depan (Tandelilin, 2009). Sri dalam Muhammad (2014) berpendapat bahwa dalam berinvestasi bank syariah memiliki prinsip untuk tidak pernah merugi, dan kemungkinan tersebut tidak akan tejadi selama bank tidak ikut menanggung kerugian yang dialami oleh nasabahnya. Bila bank harus menghadapi kerugian, ada beberapa masalah yang akan terjadi, yaitu nasabah kreditur berinvestasi pada bank syariah dengan tujuan untuk mendapatkan keuntungan semaksimal mungkin dari setiap dana yang mereka miliki dan telah dipercayakan kepada bank syariáh untuk dikelola.

Suatu Investasi dapat dilakukan di dalam pasar modal. Pasar modal merupakan elemen penting dalam pembangunan perekonomian nasional suatu negara termasuk Indonesia, hal ini dapat dilihat dari banyaknya industri dan perusahaan 
nasional yang menggunakan institusi ini sebagai media untuk menyerap investasi. Sebab pasar modal merupakan tempat bertemunya dua belah pihak, yakni pihak yang membutuhkan modal (deficit money) tersebut dengan pihak yang mempunyai kelebihan dana (surplus money), melalui terjadinya transaksi jual-beli sekuritas msaham. Jika transaksi tersebut terjadi dengan berlandaskan prinsip-prinsip syariah dan huku Islam, maka pasar modal yang dimaksud merupakan pasar modal syariah. Salah satu wadah terjadinya transaksi memperjualbelikan sekuritas atau saham tersebut adalah Bursa Efek Indonesia (BEI). Salah satu lembaga yang melakukan penanaman dan penawaran saham dalam Bursa Efek Indonesia (BEI) adalah lembaga perbankan.

Secara umum bank mempunyai tiga fungsi utama yaitu menghimpun, meminjamkan dana dan melakukan jasa pengiriman uang (Andrianto dan Firmansyah, 2019), termasuk halnya bank syariah. Dalam UU No. 21 tahun 2008 disebutkan bahwa bank syariah menjalankan kegiatannya berlandaskan prinsip syariah dan hukum Islam yang telah ditetapkan dan harus menuruti fatwa yang dibuat oleh MUI. Menurut Muhith (2012), di Indonesia, bank syariah pertama kali didirikan yaitu pada tahun 1992, dan bank syariah pertama tersebut adalah Bank Muamalat. Perkembangan dari pertumbuhan Bank berbasis Syariah di Indonesia agak terlambat dibandingkan dengan negara-negara lain. Perkembangannya mulai meningkat setelah dilengkapi dengan landasan hukum bank syariah yaitu Undang-Undang No. 21 Tahun 2008, sampai saat ini perkembangannya dapat dilihat dari peningkatan jumlah unit beserta total aset bank syariah yang semakin baik. Hal ini membuktikan adanya kepercayaan masyarakat terhadap sistem perbankan syariah di Indonesia.

Pada tahun 2020 perbankan syariáh di Indonesia terdapat 14 Bak Umum Syariáh (BUS), 20 Unit Usaha Syariáh (UUS), dan 163 Bank Pembiayaan Rakyat Syariah (BPRS) di Indonesia. Perbaankan syariah sudah menunjukkan trend perkembangan yang positif dilihat dari perusahaan bank syariah yang mulai berkontribusi mendaftarkan perusahaannya sebagai emiten dalam Bursa Efek Indonesia (BEI). Namun saat ini baru ada 3 BUS yang telah mendaftarkan perusahaannya sebagai emiten dalam Bursa Efek Indonesia (BEI), yaitu PT Bank Panin Dubai Syariah Tbk tercatat sebagai emiten dalam BEI sejak tanggal 15 Januari 2015, PT Bank BTPN Syariah Tbk tercatat sebagai emiten dalam BEI sejak tanggal 8 Mei 2018, dan PT Bank BRISyariah Tbk tercatat sebagai emiten 
dalam BEI sejak tanggal 9 Mei 2018.

Di dalam panduan go public, BEI menyatakan bahwa perusahaan akan mendapatkan beberapa keuntungan setelah go public. Namun pernyataan tersebut realitasnya tidak terjadi pada beberapa perusahaan setelah go public. Di dalam penelitian yang dilakukan oleh Khatami, dkk., (2017) tentang "Analisis Kinerja Keuangan Perusahaan Sebelum dan Sesudah Initial Public Offering (IPO) di Bursa Efek Indonesia (BEI)" menyatakan bahwa kinerja keuangan emiten BEI tidak mengalami perbedaan yang menguntungkan setelah go public. Hasil penelitian tersebut didukung dengan adanya penelitian yang dilakukan oleh Sugianto (2016) tentang "Analisis Kinerja Keuangan Sebelum dan Sesudah Go Public pada PT Garuda Indonesia Tbk tahun 2007-2014" bahwa tidak terdapat perbedaan yang berdampak pada kinerja keuangan emiten BEI sesudah go public. Hasil-hasil penelitian tersebut didukung oleh pendapat dari Narsiwan dalam Paulina (2010: 476) mengenai kineja perusahaan satu tahun setelah Initial Public Offering (IPO) atau go publics di BEI ternyata mengalami penurunan.

Selain itu fenomena yang terjadi seperti pada suatu perusahaan yang bergerak dalam bidang indsutri teknologi handphone (telepon genggam) yaitu dengan merek xiaomi. Pada tahun 2019, nilai perusahaan dari saham perusahaan xiaomi tersebut sempat mengalami penurunan yang membuat CEO (Chief Executive Officer) sekaligus founder dari perusahaan itu Lei Jun, mengeluarkan sejumlah dana pribadinya untuk membeli saham perusahaannya tersebut sebagai cara dan solusi untuk menanggulangi penurunan saham yang terus menerus mengalami penurunan. Peristiwa membeli saham perusahaannya sendiri tersebut dinamakan dengan buyback. Pada tahun 2019, perusahaan xiaomi telah mengalami kerugian sebesar sepertiga dari nilai sahamnya di tahun yang sama dan merupakan setengah dari nilai saham perusahaan tersebut pada saat perusahaan melakukan go public atau Initial Public Offering (IPO). Penurunan pada perusahaan xiomi tersebut berdampak pada kepuasan para investor, mereka sangat kecewa karena penurunan pada saham perusahaan xiomi yang luar biasa.

Karena itu, kondisi dari bank syariah setelah go public perlu diperhatikan, salah satunya adalah kinerja keuangan dari bank tersebut karena ketika rasio kinerja keuangan perusahaan baik, maka menunjukkan keadaan bank yang sehat. Kinerja keuangan perusahaan berkaitan erat dengan pengukuran dan penilaian kinerja. 
Pengukuran kinerja (performing measurument) adalah upaya yang dilakukan untuk mengukur tingkat keberhasilan aktivitas bisnis berdasarkan standar dan kriteria yang telah ditetapkan, juga bagaimana tingkat pencapaian keberhasilan perusahaan apakah sudah sesuai dengan target, sehingga penyimpangan yang terjadi dapat diteliminasi melalui proses perbaikan yang berkesinambungan (Hery, 2017). Karena sebagaimana tertuang pada UU Nomor 21 tahun 2008 Tentang Perbankan Syariah, bank syariah harus senantiasa menjaga kondisi kesehatan bank. Kesehatan bank mencerminkan kondisi dan kinerja yang diawasi oleh otoritas pengawas, jika kondisi dari suatu bank dinyatakan sehat hal tersebut mengartikan bahwa performa dari bank sudah diawasi dengan baik. Mulyadi dalam Sugianto (2016) berpendapat bahwa ada beberapa tujuan yang dicapai oleh perusahaan dalam melakukan penilaian terhadap kinerja dari perusahaan, yaitu: pertama, menyesuaikan dan menetapkan kontribusi divisi-divisi dalam suatu perusahaan agar sesuai dengan porsinya masing-masing atau secara keseluruhan, ataupun per sub divisi dari suatu divisi atau perusahaan. Kedua, untuk melakukan evaluasi terhadap manajer dalam suatu perusahaan tersebut. Ketiga, supaya para manajer divisi yang ada di dalam sebuah perusahaan dapat bekerja dengan konsisten dalam mengoperasikan kegiatan dan kontribusinya terhadap perusahaan sehingga sesuai dengan visi dan misi serta tujuan pokok dari perusahaan tersebut.

\section{Metode Penelitian}

Penelitian ini menggunakan metode RGEC sebagai sampel. Metode ini adalah suatu metode pengganti metode sebelumnya yakni metode CAMELS dan berlaku mulai tahun 2012. Pengukuran dengan metode RGEC pada tingkat kesehatan bank lebih baik dibandingkan menggunakan metode CAMELS, karena dapat menunjukkan tingkat kesehatan bank menyeluruh melalui risiko-risiko perusahaan (Amelia dan Aprilianti, 2018). Faktor-faktor yang menjadi alat ukur penilaian yang dimaksud dikeluarkan PBI No.13/1/PBI/2011 tentang penilaian metode RGEC yaitu:

\section{Risk profil (profil risiko)}

Yaitu faktor untuk mengukur risiko pada kegiatan bisnis dan kualitas manajemen risiko operasional bank. Risiko tersebut adalah risiko kredit, strategik, kepatuhan, reputasi, pasar, hukum, likuiditas dan operasional. Rasio NPF untuk 
mengukur rendah atau tingginya pembiayaan yang bermasalah di dalam suatu bank khususnya dengan prinsip syariah. Wibowo dan Syaichu (2013) dalam Yusuf dan Surjaatmadja (2018) berpendapat bahwa NPF adalah kredit atau pembiayaan bermasalah di mana debitur tidak bisa melunasi pembayaran dalam jangka waktu dalam perjanjian yang telah disepakati.

Ditetapkan batas aman NPF sebesar 5\% menjadi angka toleransi bagi kesehatan suatu bank. Rahmat (2012) berpendapat bahwa jika nilai rasio NPF makin rendah atau makin kecil, maka semakin baik pula kinerja bank, bank menghasilkan keuntungan yang baik. Dan sebaliknya, semakin tinggi nilai rasio dari NPF maka semakin buruk atau rendahnya kinerja dari bank tersebut, semakin rendahnya kemampuan bank dalam mengumpulkan kembali pembiayaan yang dikeluarkannya dan mengakibatkan menurunnya tingkat kesehatan dalam suatu bank tersebut, sehingga bank berisiko tinggi akan mengalami kerugian karena tingkat pengembalian kredit macet. Nilai rasio NPF pada tahun $2014-2018$ mengalami penurunan, penurunan rasio pembiayaan bermasalah ini terjadi dikarenakan adanya pertumbuhan pada pembiayaan bank syariah dalam kurun waktu 5 tahun terakhir tersebut.

Selain menggunakan nilai rasio Non Performing Financing (NPF), digunakan juga rasio Financing to Deposit Ratio (FDR). Dalam bank konvensional dikenal dengan nama Loans to Deposit Ratio (LDR), karena dalam perbankan syariah tidak ada kredit, maka dalam perbankan syariah dikenal dengan nama Financing to Deposit Ratio (FDR). Penggunaan nilai rasio FDR, karena nilai rasio FDR mengukur likuiditas bank terhadap DPK (Dana Pihak Ketiga). Riyadi (2015) berpendapat bahwa rasio ini menunjukkan tingkat kemampuan bank dalam menyalurkan dananya yang berasal dari masyarakat (berupa: Giro, Tabungan, Deposito Berjangka, Sertifikat Deposito Berjangka dan Kewajiban Segera lainnya) dalam bentuk kredit. Wardana dan Widyarti (2015) dalam Yusuf dan Surjaatmadja (2018) menyatakan bahwa nilai rasio FDR menunjukkan efektifitas penyaluran pembiayaan bank, jika nilai rasio FDR terlalu tinggi, likuiditas semakin berisiko namun laba yang didapatkan tinggi. Jika nilai rasio FDR rendah, bank dianggap tidak efektif mengumpulkan dana dan menyalurkan dari dari pelanggan kemudian berakibat pada laba yang didapatkan oleh perusahaan. 


\section{Good Corporate Governance (GCG)}

GCG menunjukkan suatu mekanisme praktik bisnis yang sehat dan hal ini menjadi nilai tambah bagi para investor. Penerapan GCG pada perusahaan dapat meningkatkan kualitas dari laporan keuangan dan meminimalisir atau menghambat terjadinya rekayasa kinerja dari perusahaan (Halimatusadiah dan Gunwan, 2014). GCG adalah salah satu indikator nilai perusahaan, jika sudah baik maka menggambarkan bahwa perusahaan dalam kondisi yang baik. Untuk mencapai nilai perusahaan yang baik maka faktor eksternal dan faktor internal perusahaan harus berupaya semaksimal mungkin meningkatkan nilai perusahaan. GCG dalam suatu perusahaan akan terlihat sangat lemah ketika terjadi tindakan yang mementingkan perusahaan itu sendiri kemudian mengabaikan kepentingan dari investor (Franita, 2018). Adapun tahapan-tahapan proses yang akan dilalui oleh emiten yang akan mendaftarkan sahamnya saat go public, akan mengalami proses sebagai berikut:

a. Perusahaan harus menunjuk underwriter dan menyiapkan dokumen dan segala hal lainnya yang diperlukan untuk disampaikan kepada Bursa Efek Indonesia (BEI).

b. Kemudian, calon emiten dapat memohon pencatatan sahamnya ke BEI untuk dikolektifkan (scriptless) di Kustodian Sentral Efek. BEI akan menelaah permohonan tersebut dan mengundang perusahaan tersebut dengan underwriter dan tim internal lainnya, mempresentasikan dokumen-dokumen tersebut, kemudian BEI akan melakukan kunjungan pada perusahaan tersebut.

c. Setelah itu, perusahaan menyampaikan pernyataan pendaftaran ke OJK dengan mempublikasikan prospektus ringkas di surat kabar atau melakukan penawaran awal, namun perusahaan harus menunggu izin dari OJK terlebih dahulu.

d. Lalu, perusahaan melakukan penawaran umum kepada publik yang dilakukan selama 1-5 hari kerja.

e. Akhirnya perusahaan menyampaikan permohonan pencatatan saham kepada BEI disertai dengan bukti surat pernyataan pendaftaran bahwa perusahaan telah efektif OJK, dokumen prospektus dan laporan komposisi pemegang saham perusahaan. Setelah disetujui oleh BEI, maka BEI memberikan pengumuman pencatatan saham perusahaan dan kode saham perusahaan. Setelah tercatat 
di OJK, maka investor dapat memperjualbelikan saham perusahaan kepada investor lain melalui broker atau Perusahaan Efek yang menjadi Anggota Bursa terdaftar di Bursa Efek Indonesia (BEI).

\section{Earnings (rentabilitas)}

Rentabilitas merupakan kemampuan bank atau perusahaan memperoleh laba menggunakan modal perusahaan tersebut (Utama, 2015). Untuk mengukur rentabilitas digunakan rasio ROA rasio ROE dan rasio NOM. Rasio ROA mengukur kemampuan bank atau perusahaan menghasilkan laba dari investasi yang dilakukan perusahaan, Wahyuningsih, dkk (2015) dalam Yusuf dan Surjaatmadja (2018) berpendapat bahwa jika nilai rasio ROA suatu perusahaan makin tinggi maka penggunaan aset perusahaan sudah efisien sehingga akan memperbesar keuntungan yang didapatkan.

ROE (Return on Equity) mengukur tingkat kemampuan bank atau perusahaan menghasilkan keuntungan berupa laba dari penggunaan modal perusahaan dan menghasilkan laba bagi investor. Semakin tinggi rasio tersebut maka menunjukkan bahwa kinerja suatu perusahaan semakin efektif. Peningkatan pada harga saham perusahaan akan meningkatkan penyediaan laba bagi investor (Saragih, 2017). Rasio NOM (Net Operating Margin) mengukur tingkat perusahaan mengelola aktiva produktif sehingga memperoleh laba yang bersih. Rasio NOM pada bank syariah harus bernilai positif, karena hal itu menunjukkan bahwa investasi yang dilakukan tidak lebih besar dibandingkan dengan hasil yang didapatkan.

\section{Capital (permodalan)}

Muhammad (2014) berpendapat bahwa baik bank nasional maupun internasional harus memenuhi rasio kecukupan modalnya (Capital Adequacy Ratio). Capital (pemodalan) merupakan aspek penting bagi dunia perbankan. Menurut Pramana dalam Wahasusmiah dan Watie (2018) bank harus mengikuti ketentuan yang ditetapkan oleh BI yang mengatur KPMM. Permodalan dari bank perlu diperhatikan karena merupakan gambaran struktur permodalan dari suatu perusahaan (Suangkupon, dkk., 2014). CAR merupakan aspek penting bagi dunia perbankan. Bank harus memelihara modal yang cukup untuk mendukung aktivitas pengambilan risiko (risk taking). Peranan modal sangat penting di mana kegiatan operasional bank dapat berjalan dengan lancar apabila memilki modal 
yang cukup, sehingga pada saat masa-masa kritis bank tetap aman karena memiliki cadangan modal di Bank Indonesia (Kasmir, 2008).

Lukman dalam Defri (2012) berpendapat bahwa bank yang tidak memiliki kecukupan modal maka bank tersebut bisa dikatakan tidak sehat rasionya, sehingga bank tersebut masuk dalam kriteria bank dalam pengawasan khusus karena rasio kecukupan modal (CAR)-nya di bawah standar yang ditetapkan Bank Indonesia (8\%). Sehingga kemampuan bank untuk survive pada saat bank mengalami kerugian dan juga mengakibatkan turunnya kepercayaan nasabah yang pada akhirnya dapat menurunkan profitabilitas bank. Semakin tinggi nilai rasio Capital Adequacy Ratio (CAR) atau KPMM (Kewajiban Penyediaan Modal Minimum) maka modal dari suatu bank meningkat, semakin besar pula sumber daya finansial maka semakin tinggi pula kemampuan bank dalam meminimalisir kerugian yang diakibatkan oleh penyaluran kredit yaitu kredit bermasalah (NonPerforming Financing), artinya bank tersebut mampu menutupi risiko pembiayaan dengan besarnya cadangan dana yang diperoleh dari perbandingan modal dan Aktiva Tertimbang Menurut Risiko (ATMR).

Penelitian ini merupakan penelitian kuantitatif karena data-data di dalam penelitan ini adalah data berupa angka-angka yang berdasarkan pada laporan keuangan dari perusahaan yang telah melakukan go public. Populasi dari penelitian ini adalah Bank Umum Syariah (BUS) yang telah mendaftarkan diri dan mencatatkan sahamnya serta melakukan penawaran saham perdana di BEI. Sampel adalah sebagian dari jumlah populasi yang akan dipilih menjadi sumber data yang memiliki karakteristik yang sama dengan populasi (Widiyanto, 2013). Sampel dalam penelitian ini diambil dengan cara purposive sampling, yaitu dengan berdasarkan pada beberapa kriteria-kriteria yang diambil. Sampel untuk penelitian ini yaitu PT Bank BRI Syariah Tbk, setelah melalui beberapa pertimbangan kriteria seperti:

a. BUS yang tercatat di dalam BEI;

b. Telah mempublikasikan laporan kinerja keuangan triwulan dan laporan pelaksanaan GCG bank;

c. Memiliki total aset terbesar pada triwulan I 2019 dengan data pendukung dan dibutuhkan. 
Penelitian ini menggunakan data sekunder karena data yang diambil merupakan data laporan kinerja keuangan yang telah dipublikasi dalam situs resmi PT Bank BRISyariah Tbk dalam kurun waktu sebelum go public yaitu Triwulan II 2017 - Triwulan I 2018 dan setelah go public yaitu Triwulan II 2018 - Triwulan 12019 dan sebelum BRISyariáh Merger menjadi BSI. Selain itu, diambil data laporan GCG untuk melengkapi penelitian dengan menggunakan metode RGEC. Berikut ini merupakan rasio-rasio yang digunakan dengan metode RGEC:

a. Non-Performing Financing (NPF)

Wibowo dan Syaichu (2013) dalam Yusuf dan Surjaatmadja (2018: 128) berpendapat bahwa NPF adalah kredit atau pembiayaan bermasalah di mana debitur tidak bisa melunasi pembayaran tepat waktu sesuai dengan kesepakatan. Rumus:

$$
N P F=\frac{\text { Pembiayaan }(k l, d, m)}{\text { total pembiayaan }} \times 100 \%
$$

b. Financing to Deposit Ratio (FDR)

Wardana dan Widyarti (2015) dalam Yusuf dan Surjaatmadja (2018: 128) menyatakan bahwa nilai rasio FDR menunjukkan bank menyalurkan pembiayaan dengan efektif. Jika nilai FDR tinggi, likuiditas semakin berisiko, namun laba yang didapatkan tinggi. Rumus:

$$
F D R=\frac{\text { Total Pembiayaan }}{\text { Total dana pihak ketiga }} \times 100 \%
$$

c. Return on Aset (ROA)

ROA mencerminkan kemampuan perusahaan atau bank dalam menghasilkan keuntungan (laba) dalam periode waktu tertentu. Jika tingkat rasio ROA tinggi maka laba atau keuntungan yang diperoleh pun tinggi. Rumus:

$$
R O A=\frac{\text { Laba sebelum pajak }}{\text { rata }- \text { rata total aset }} \times 100 \%
$$

d. Return on Equity (ROE)

Rasio ROE mengukur kemampuan perusahaan menghasilkan laba dari modal perusahaan, serta laba bersih untuk investor. Semakin tinggi rasio ROE maka menunjukkan bahwa kinerja suatu perusahaan semakin efektif. Peningkatan pada harga saham perusahaan akan meningkatkan penyediaan laba bagi investor (Saragih, 2017: 351). Rumus untuk menghitung rasio ROE adalah 
sebagai berikut:

$$
R O E=\frac{\text { Laba setelah pajak }}{\text { total ekuitas }} \times 100 \%
$$

e. Net Operating Margin (NOM)

Nilai rasio NOM mengukur tingkat perusahaan mengelola aktiva produktif sampai menghasilkan laba. NOM pada bank syariah harus bernilai positif, karena hal itu menunjukkan bahwa investasi yang dilakukan tidak lebih besar dibandingkan dengan hasil yang didapatkan (Junita, 2015).

$$
\text { NOM }=\frac{(\text { PO }- \text { Dana bagi hasil })-B O}{\text { rata }- \text { rata aktiva produktif }} \times 100 \%
$$

f. $K P M M$ (Kewajiban Penyediaan Modal Minimum)

Permodalan dari bank perlu diperhatikan karena merupakan gambaran struktur permodalan dari suatu perusahaan (Suangkupon, dkk., 2014: 129). Rasio KPMM 8\% dinilai “Sehat” dengan nilai kredit 81, setiap kenaikan 0,1\% maka nilai kredit tersebut ditambah 1. Jika nilai rasio kurang dari 8\% - 7,9\% diberi predikat "Kurang Sehat" dengan nilai kredit 65. Untuk penurunan setiap 0,1\% nilai kredit dikurangi 1 (Kodifikasi Peraturan Bank Indonesia). Rumus:

$$
C A R=\frac{\text { Modal }}{A T M R} \times 100 \%
$$

\section{g. Good Corporate Governance (GCG)}

GCG merupakan cerminan dari tata kelola perusahaan yang baik, sehingga jika tata kelola perusahaan sudah baik artinya kondisi dari bank atau perusahaan tersebut sehat dan kinerjanya baik.

\section{Hasil dan Pembahasan}

Sebelum menjadi perusahaan publik, suatu perusahaan masih dianggap sebagai perusahaan pribadi atau disebut juga perusahaan swasta. Perusahaan swasta memiliki investor yang relatif kecil dan sedikit yaitu seperti keluarga pemilik perusahaan, pendiri perusahaan, teman pemilik perusahaan dan sebagainya. Ketika perusahaan telah bertumbuh dan berkembang serta siap menjadi perusahaan publik, perusahaan tersebut harus mampu mentataati dan mengikuti ketentuan dan peraturan yang berlaku seperti menerapkan prinsip-prinip go public serta 
memiliki tanggung jawab terhadap perusahaan. Keuntungan yang didapatkan oleh perusahaan setelah melakukan go public adalah (IDX BEI; tt) :

a. Memperoleh Sumber Pendanaan Baru

b. Memberikan Keunggulan Kompetitif (Competitive Advantage) untuk Pengembangan Usaha

c. Melakukan merger atau akuisisi perusahaan lain dengan pembiyaan melalui penerbitan saham baru.

d. Peningkatan Kemampuan Going Concern yaitu kemampuan untuk tetap dapat bertahan dalam kondisi apapun termasuk dalam kondisi yang dapat mengakibatkan bangkrutnya perusahaan, seperti terjadinya kegagalan pembayaran utang kepada pihak ketiga, perpecahan di antara para pemegang saham pendiri, atau bahkan karena adanya perubahan dinamika pasar yang dapat mempengaruhi kemampuan perusahaan untuk tetap dapat bertahan di bidang usahanya

e. Meningkatkan Citra Perusahaan (Company Image)

f. Meningkatkan Nilai Perusahaan (Company Value)

Penerbitan saham kepada khalayak publik memungkinkan perusahaan atau bank mengumpulkan modal yang didapatkan dari investor dari saham publik. Waktu pergantian pada saat suatu perusahaan swasta menjadi suatu perusahaan publik merupakan waktu yang penting untuk investor swasta supaya dapat sepenuhnya merealisasikan keuntungan yang didapatkan dari investasi yang telah dilakukan oleh pada investor tersebut karena biasanya termasuk premi saham untuk investor swasta saat ini. Sementara itu, itu juga memungkinkan investor publik untuk berpartisipasi dalam penawaran saham perusahaan tersebut. Menurut Darmadji dan Hendy (2006) terdapat beberapa konsekuensi yang ditanggung perusahaan jika melakukan penawaran umum, yaitu: (1) Keharusan untuk melakukan keterbukaan (full disclosure), (2) Keharusan untuk mengikuti peraturan-peraturan pasar modal mengenai kewajiban pelaporan, (3) Gaya manajemen perusahaan berubah dari informal menjadi formal, (4) Kewajiban membayar deviden bila perusahaan mendapat laba, (5) Senantiasa berusaha meningkatkan tingkat pertumbuhan perusahaan.

Kinerja atau performa dari perbankan syariah setelah go public seharusnya 
semakin meningkat, dan konsisten menjaga kepercayaan dari para investor terhadap bank syariah dengan mempertahankan performanya agar tetap bagus, sehingga calon investor bank syariah yakin bahwa prospek industri bank syariah akan cerah pada masa mendatang. Menurut Pastusiak, dkk., (2016) alasan apapun yang menjadi latar belakang dari perusahaan memutuskan untuk go publics, go publics akan berdampak pada perusahaan, yaitu pada segi akuntansi perusahaan, kegiatan operasional perusahaan, dan tentunya akan berdampak pada keuangan perusahaan.

Bank syariáh yang sudah go public harus dapat meningkatkan sektor kinernya pada skala yang lebih baik terumtam pda kinerja keuangan yang mencerminkan prospek pertumbuhan dan perkembangan keuangan suatu perusahaan dalam mengoptimalkan sumber daya perusahaan yang dimiliki oleh perusahaan tersebut. Darsono dalam Fadli, dkk (2012) bahwa kinerja keruangan adalah suatu hal yang dihasilkan dari operasional kegiatan suatu perusahaan yang disajikan dan diyatakan dalam bentuk angka-angka tentang keuangan. Keadaan keuangan suatu perusahaan dapat diukur dengan menggunakan alat ukur yaitu berupa rasio keuangan bank dalam laporan keuangan bank tersebut. Hussain, dkk. (2012) berpendapat bahwa risiko kredit, risiko likuiditas, dan risiko operasional merupakan rasio penting dan terbanyak dihadapi oleh perbankan syariah dibandingkan bank konvensional dan dilihat dari prospeknya perbankan syariah semakin membaik dan positif.

Contoh rasio untuk mengukur kinerja keuangan bank adalah rasio NPF (Non Performing Financing) untuk mengukur rendah atau tingginya pembiayaan bermasalah atau besarnya risiko kredit dalam bank khususnya bank syariah, rasio FDR (Financing to Deposit Ratio) untuk mengukur rendah atau tingginya risiko likuiditas bank terhadap DPK, rasio ROA (Return on Asset) untuk mengukur tingkat kemampuan perusahaan menghasilkan laba yang berasal dari kegiatan investasi perusahaan tersebut. Wahyuningsih, dkk (2015) dalam Yusuf dan Surjaatmadja $(2018,126)$ menegaskan bahwa semakin besar rasio ROA, semakin efisien penggunaan aset perusahaan tersebut sehingga akan memperbesar keuntungan yang didapatkan oleh perusahaan.

Kemudian rasio ROE (Return on Equity) untuk mengukur kemampuan perusahaan menghasilkan laba dari penggunaan modal perusahaan, dan menghasilkan keuntungan yang bersih untuk investor, rasio NOM (Net Operating 
Margin) untuk mengukur kemampuan perusahaan memanajemen perusahaan mengelola aktiva produktif, sehingga menghasilkan laba bersihrasio KPMM (Kewajiban Penyediaan Modal Minimum) untuk mengukur tingkat kecukupan modal suatu perusahaan dalam berkegiatan secara efisien, dan laporan GCG (Good Corporate Governance) digunakan untuk mengetahui apakah perusahaan sudah mengelola perusahaan sehingga tertata dengan baik. Adapun uji penelitiaan yang dilakukan adalah sebagai berikut:

1. Hasil Uji Normalitas

Tabel 1. Uji Normalitas Shapiro-Wilk

\begin{tabular}{ccccc}
\hline \multirow{2}{*}{ Kode Waktu } & \multicolumn{3}{c}{ Shapiro-Wilk } \\
\hline \multirow{2}{*}{ NPF } & Sebelum & .967 & 4 & .826 \\
& Setelah & .752 & 4 & .040 \\
\multirow{2}{*}{ FDR } & Sebelum & .992 & 4 & .966 \\
& Setelah & .972 & 4 & .856 \\
\multirow{2}{*}{ ROA } & Sebelum & .909 & 4 & .477 \\
& Setelah & .843 & 4 & .205 \\
\multirow{2}{*}{ ROE } & Sebelum & .827 & 4 & .159 \\
& Setelah & .866 & 4 & .283 \\
\hline
\end{tabular}

Sumber: Data sekunder yang telah diolah

Pada tabel 1. semua rasio kinerja keuangan sebelum go public berdistribusi dengan normal karena nilai signifikan lebih besar dari 0.05, kecuali rasio NPF setelah go public. Maka digunakan uji non parametric wilcoxon. 
2. Hasil Uji Wilcoxon

Tabel 2. Test Statistics

\begin{tabular}{lcc}
\hline & Z & $\begin{array}{c}\text { Asymp. Sig. } \\
\text { (2-tailed) }\end{array}$ \\
\hline NPF Sebelum go public - NPF Setelah go public & -1.826 & .068 \\
FDR Sebelum go public - FDR Setelah go public & -1.826 & .068 \\
ROA Sebelum go public - ROA Setelah go public & -.730 & .465 \\
ROE Sebelum go public - ROE Setelah go public & -1.461 & .144 \\
NOM Sebelum go public - NOM Setelah go public & -1.095 & .273 \\
KPMM Sebelum go public - KPMM Setelah go public & -1.826 & .068 \\
\hline
\end{tabular}

Sumber: Data sekunder yang telah diolah

a. Non Performing Financing (NPF)

Dilihat di tabel 2. rasio NPF memiliki nilai signifikansi sebesar 0,068/2= 0,034 . Hasil yang didapatkan adalah $0,034<0,05$. Nilai derajat kesalahan lebih besar dibandingkan nilai signifikansinya, sehingga hipotesis 1 diterima, maka terdapat perbedaan pada NPF PT Bank BRISyariah Tbk sebelum go public dan sesudah go public.

b. Financing to Deposit Ratio (FDR)

Dilihat di tabel 2. rasio FDR, memiliki nilai signifikansi sebesar 0,068/2= 0,034 . Hasil yang didapatkan adalah $0,034<0,05$. Nilai derajat kesalahan lebih besar dibandingkan nilai signifikansinya, sehingga hipotesis 2 diterima, maka terdapat perbedaan pada FDR PT Bank BRISyariah Tbk sebelum go public dan sesudah go public.

c. Return on Asset (ROA)

Dilihat di tabel 2. rasio ROA memiliki nilai signifikansi sebesar 0,465/2= 0,2325 . Hasil yang didapat adalah $0,2325>0,05$. Nilai derajat kesalahan lebih kecil dibandingkan nilai signifikansinya, sehingga hipotesis 4 ditolak, maka tidak terdapat perbedaan pada ROA PT Bank BRISyariah Tbk sebelum go public dan sesudah go public.

d. Return on Equity (ROE) 
Dilihat di tabel 2. rasio ROE memiliki nilai signifikansi sebesar $0,144 / 2=$ 0,072 . Hasil yang didapat adalah $0,072>0,05$. Nilai derajat kesalahan lebih kecil dibandingkan nilai signifikansinya, sehingga hipotesis 5 ditolak, maka tidak terdapat perbedaan pada ROE PT Bank BRISyariah Tbk sebelum go public dan sesudah go public.

e. Net Operating Margin (NOM)

Dilihat di tabel 2. rasio NOM memiliki nilai signifikansi sebesar 0,273/2 $=0,1365$ yang jika dibandingkan dengan derajat kesalahan yang telah ditetapkan yaitu sebesar 0,05, hasil yang didapat adalah 0,1365>0,05. Nilai signifikan lebih besar dibandingkan derajat kesalahan sehingga hipotesis 6 ditolak, maka tidak terdapat perbedaan dan pada NOM PT Bank BRISyariah Tbk sebelum go public dan sesudah go public.

f. Capital Adequacy Ratio (CAR)

Dilihat di tabel 2. rasio CAR memiliki nilai signifikansi sebesar 0,068/2 $=0,034$ hasil yang didapat adalah 0,034<0,05. Nilai derajat kesalahan lebih besar dibandingkan signifikansinya, sehingga hipotesis 7 diterima, maka terdapat perbedaan pada kinerja rasio CAR PT Bank BRISyariah Tbk sebelum go public dan sesudah go public.

g. Penilaian terhadap Good Corporate Governance (GCG)

Dalam laporan pelaksanaan GCG pada PT Bank BRISyariah Tbk yaitu pada periode sebelum mendaftarkan perusahan go public tahun 2017 mendapatkan skor/nilai komposit sebesar 1,57 namun GCG pada PT Bank BRISyariah Tbk sesudah mendaftarkan perusahaan go public yaitu pada tahun 2018 mendapatkan skor/nilai komposit sebesar 1,54. Terdapat perbedaan nilai sebelum dan sesudah go public sebesar 0,03, namun keduanya masih mendapatkan predikat baik.

Hasil dari pelaksanaan GCG PT Bank BRI Syariah Tbk memperlihatkan bahwa setelah bank go public, skor/nilai dari pelaksanaan GCG dari bank menurun. Hal ini menunjukkan bahwa pelaksanaan GCG membaik namun tidak terlalu berdampak pada perusahaan karena perbedaannya sangat kecil yaitu hanya 0,03.

\section{Simpulan}


Tulisan ini menunjukkan bahwa performa perbankan syariah setelah Initial Public Offering (IPO) lebih baik daripada performa perbankan syariah sebelum Initial Public Offering (IPO) walaupun tidak terlalu signifikan. Hal ini dapat dilihat dari hasil berikut ini: (1) Hasil uji non parametrik wilcoxon pada kinerja keuangan PT Bank BRISyariah Tbk menunjukkan bahwa terdapat perbedaan yang cukup besar pada rasio KPMM, sedangkan pada rasio NPF dan FDR terdapat perbedaan namun perbedaan tersebut tidak terlalu besar, dan pada rasio ROA, ROE, dan NOM tidak terdapat perbedaan pada kinerja PT Bank BRISyariah Tbk sebelum dan sesudah IPO. Untuk variabel GCG sendiri menunjukkan perbedaan, namun tidak terlalu berpengaruh terhadap perusahaan karena perbedaannya cenderung kecil. (2) Perbedaan kinerja PT Bank BRISyariah sebelum dan sesudah IPO dapat dilihat pada rasio-rasio kinerja keuangan NPF, FDR, ROA, ROE, NOM, dan KPMM. Kinerja FDR dan KPMM sesudah IPO lebih baik dibandingkan kinerja sebelum IPO. Sedangkan kinerja NPF, ROA, ROE, dan NOM sesudah IPO tidak lebih baik dibandingkan sebelum IPO, begitu pula dengan penilaian pada kinerja GCG.

\section{Daftar Rujukan}

Abu Hussain, Hameeda and Al-Ajmi, Jasim. (2012). Risk management practices of conventional and Islamic banks in Bahrain. Bahrain: Department of Economics and Finance, University of Bahrain, Sekheer.

Andrianto dan Firmansyah. (2019). Manajemen Bank Syariah. Pasuruan: Penerbit Qiara Media.

Bursa Efek Indonesia (BEI). (2020). Manfaat Go Public. Diakses pada bulan Januari 2020, dari https://gopublic.idx.co.id/2016/06/22/manfaat-gopublic/.

Darmadji, Tjiptono dan Hendy, M. Fakhruddin (2006). Pasar Modal di Indonesia: Pendekatan Tanya-Jawab, Edisi 2, Jakarta: Salemba Empat.

Defri, (2012), Pengaruh Capital Adequacy Ratio, Likuiditas Dan Efisiensi Operasional Terhadap Profitabilitas Perusahaan Perbankan Yang terdaftar di BEI, Jurnal Manajemen, vol 1, no 1, 1-18. 
Dintha dan Supriatna. (2019). Pengaruh Initial Public Offering (IPO) Terhadap Kinerja Perusahaan. Jurnal Riset Akuntansi dan Keuangan: Vol. 7 (1), 19-28. Fadli, UM, dkk. (2012). Pengaruh Kepuasan Kerja Terhadap Kinerja Dosen Universitas Singaperbangsa Karawang. Jurnal Manajemen 9 (2), 678-70.

Franita, Riska. (2018). Mekanisme Good Corporate Governance dan Nilai Perusahaan: Studi Untuk Perusahaan Telekomunikasi. Medan: Lembaga Penelitian dan Penulisan Ilmiah AQLI.

Halimatusadiah, Ellie dan Gunawan, Bangun. (2014). Analasisis Penerapan Good Corporate Governance Dalam Mengoptimalkan Pelaksanaan Sistem Informasi Akuntansi. Jurnal Riset Akunansi dan Keuangan, Vol. 2 No. 1, 3003013.

Hery, 2017, Balanced Scorecard for Business, Jakarta, PT. Grasindo, 2017.

Junita, Sherty. (2015). Pengaruh KAP, BOPO, dan FDR terhadap Net Operating Margin (NOM) Perbankan Syariah di Indonesia Periode 2010-2014: UIN Jakarta.

Khatami, Nurbaitillah dkk. (2017). Analisis Kinerja Keuangan Perusahaan Sebelum dan Sesudah Initial Public Offering (IPO) di Bursa Efek Indonesia. Jurnal Administrasi Bisnis (JAB) Vol. 47 No. 1, 88-94.

Kusumawardani, Angrawit. (2014). Analisis Perbandingan Tingkat Kesehatan Bank Dengan Menggunakan Metode CAMELS dan RGEC pada PT Bank XXX Periode 2008 - 2011. Jurnal Ekonomi Bisnis, Vol. 19, No. 03, 16-22.

Muhammad. (2014). Manajemen Dana Bank Syariah. Jakarta: Rajawali Pers.

Muhith, Abdul. (2012). Sejarah Perbankan Syariah. Attanwir: Jurnal Kajian Keislaman dan Pendidikan, Volume 01, Nomor 02, September 2012.

OJK. (2018). Statistik Perbankan Syariah 2018. Dokumen diakses pada 24 Juni 2019 melalui www.ojk.go.id.

Pastusiak, Radoslaw dkk. (2016). Company profitability before and after ipo. Is it a windows dressing or equity dilution effect?. Faculty of Economics and Sociology, University of Lodz. Lodz. Poland. Prague Economic Papers 25 (1).

Paulina, Saint. (2010). Analisis Reaksi Pasar Modal Setelah Pengumuman Initial Public Offering (IPO) pada Perusahaan yang Terdaftar di Bursa Efek 
Indonesia. Jurnal Wacana: Vol. 13 No. 3, 2010. 475-484.

Risqi, Indita Azisia dan Harto, Puji. (2013) Analisis Faktor-Faktor yang

Mempengaruhi Underpricing ketika Initial Public Offering (IPO) fi Bursa

Effek Indonesia, Diponergoro Journal of Accounting, Volume 2, Nomor 3, Tahun 2013, 1-7.

Saragih R. (2015). Membangun usaha kreatif, inovatif dan bermanfaat melalui penerapan kewirausahaan sosial, Jurnal Kewirausahaan 3 (2), 26-34.

Siregar, S. (2013). Statistik Parametrik Untuk Penelitian Kuantitatif: Dilengkapi Dengan Perhitungan Manual dan Aplikasi SPSS Versi 17. Jakarta: Bumi Aksara.

Suangkupon, dkk. (2014). Direktori produk kredit dan tabungan perbankan Se-kalimantan tengah tahun 2014. Kantor perwakilan Bank Indonesia perwakilan Kalimantan Tengah.

Sugianto, Vivi Yanty. (2016) Analisis Kinerja Keuangan Sebelum dan Sesudah

Go Public pada PT. Garuda Indonesia Tbk Tahun 2007-2014. Jurnal Bisnis dan Manajemen Vol. 52 No 11, 81-91.

Syafitri, dkk., (2018). Pengaruh Good Corporate Governance Terhadap Nilai Perusahaan. Jurnal Administrasi Bisnis (JAB), Vol. 56, No. 01.

Tandelilin, Eduardus. (2010). Portofolio dan Investasi: Teori dan Aplikasi. Yogyakarta: Kanisius.

Umiyati dan Faly. Pengukuran Kinerja Bank Syariah Dengan Metode RGEC. Jurnal Akuntansi dan Keuangan Islam: Vol. 2, No. 2, 2015.

Undang-Undang No. 21 Tahun 2008.

Utama, I gusti bagus rai. 2015. Pengantar Industri Pariwisata. Yogyakarta: Deepublish.

Wahasusmiah, R. dan Watie. K. (2018). Metode RGEC: Penilaian Tingkat Kesehatan Bank Pada Perusahaan Perbankan Syariah. Jurnal Raden Fatah: I-Finance: Vol. 04, No. 02.

Wirajunayasa dan Putri. (2017) Analisis Kinerja Keuangan Perusahaan Sebelum dan Sesudah Initial Public Offerings. E-Jurnal Akuntansi Universitas Udayana: Vol. 19, No. 3. 
Yusuf, Muhammad and Surjaatmadja, Surachman. (2018). Analysis of Financial Performance on Profitability with Non Performance Financing as Variable Moderation (Study at Sharia Commercial Bank in Indonesia Period 20122016), International Journal of Economics and Financial Issues, 8(4), 126-132. 